\title{
IMPLEMENTATION OF RELIGIOUS CHARACTER EDUCATION IN STUDENTS THROUGH TAHFIDZ QUR'AN ACTIVITIES WITH TSAQIFA METHOD IN MUHAMMADIYAH VOCATIONAL HIGH SCHOOL 3 SURAKARTA
}

\author{
Muhammad Amir Alfaridzi ${ }^{1}$, Khabihiz Jafitri ${ }^{2}$, and Oksita Purwanti ${ }^{3}$ \\ ${ }^{1}$ Islamic Education, Universitas Muhammadiyah Surakarta, Surakarta, jibongkil@gmail.com \\ ${ }^{2}$ Islamic Education, Universitas Muhammadiyah Surakarta, Surakarta, \\ khabihizjafitri97@gmail.com \\ ${ }^{3}$ Islamic Education, Universitas Muhammadiyah Surakarta, Surakarta, \\ oksitapurwanti28@gmail.com
}

\begin{abstract}
This study aims are to describe (1) Application of tahsin and tahfidz activities with Tsaqifa method in learning the Qur'an at Muhammadiyah vocational high School 3 Surakarta. (2) Supporting and inhibiting factors of the application of the Tsaqifa method, and (3) Results in the activities of tahsin and tahfidz of the Qur'an using the Tsaqifa method. The research method used is descriptive qualitative. Sources of data in this study were teachers, students, and the learning process of the Qur'an subjects at Muhammadiyah vocational high School 3 Surakarta. The object of this study is the result of the teaching methods used by teachers in learning the Qur'an. Data collection uses interview, observation, and documentation techniques. The inhibiting factors are the large number of Qur'an reading skills still stammering, lack of interest in learning the Qur'an, and lack of infrastructure. Supporting factors namely internal factors are factors that arise from students themselves, and external factors namely family, institutional, and school environment. To overcome each problem or inhibiting factors are still being studied to find the right solution.
\end{abstract}

Keywords: implementation, Tsaqifa, tahsin, tahfidz

Abstrak. Penelitian ini bertujuan mendeskripsikan (1) Penerapankegiatan tahsin dan tahfidz dengan metode tsaqifadalam pembelajaran Alquran di SMK Muhammadiyah 3 Surakarta.(2) Faktor pendukung dan penghambat penerapan metode tsaqifa, serta (3) Hasil dalam kegiatan tahsin dan tahfidz Alquran menggunakan metode tsaqifa. Metode penelitian yang digunakan adalah deskriptif kualitatif. Sumber data dalam penelitian ini adalah guru, siswa, dan proses pembelajaran mata pelajaran Alquran di SMK Muhammadiyah 3 
Surakarta. Objek penelitian ini adalah hasil dari metode pengajaran yang digunakan guru dalam pembelajaran Alquran. Pengumpulan data menggunakan teknik wawancara, observasi, dan dokumentasi. Faktor penghambat yaitu masih banyaknya kemampuan bacaan Alquran masih terbata-bata, kurangnya ketertarikan untuk belajar Alquran, dan kurangnya sarana prasarana. Faktor pendukung yaitu faktor internal adalah faktor yang muncul dari pribadi siswa sendiri, dan faktor eksternal yaitu faktor keluarga, institusional, dan lingkungan sekolah. Untuk mengatasi setiap permasalahan atau faktor penghambat tersebut masih dikaji untuk ditemukan solusi yang tepat.

Kata Kunci: implementasi, tsaqifa, tahsin, tahfidz

\section{INTRODUCTION}

The functions and objectives of National Education are mentioned in Chapter II article 3 of Law Number 20 Year 2003 concerning the National Education System which states that national education functions to develop capabilities and shape the character and civilization of a dignified nation in order to educate the life of the nation, aiming at developing the potential of students to become people who believe and fear Almighty Allah, noble, healthy, knowledgeable, capable, creative, independent, and become citizens of a democratic and responsible. Thus, character education becomes a learning that must be internalized from the beginning at all levels of education both from the elementary level to the tertiary level.

Character education can be done with a variety of models of habituation and example, fostering discipline, rewards, and punishment, contextual learning, role-playing, and participatory learning. ${ }^{1}$ Character education of students through Qur'an-based education is intended, can make habituation and example, fostering prize discipline, and punishment, contextual learning, role playing, contextual learning, and participatory learning, which is carried out continuously and integrated by educators and students. As stipulated in Al-Alaq verses 1-5:

${ }^{1}$ Mulyasa, Manajeman Pendidikan Karakter, (Jakarta: Bumi Aksaran, 2012), 125 
"1. Read in the name of your Lord who created; 2 . He created man from a clot of blood; 3. Read, and your Lord is the most gracious; 4. who teaches (human) with intermediaries kalam; 5. He teaches humans what they don't know. (QS. Al-Alaq: 1-5)"

In this regard, a Muslim can read the Qur'an and then teach it to those who have not been able to because it is best that a Muslim learn the Qur'an and teach it.

Each school has its own way to instill character education in its students. One of the schools that also implements religious activities is Muhammadiyah vocational high School 3 Surakarta. Religious activities at the school are prayer activities in congregation, Qur'an tadarus, routine studies, practice of sacrifice and Friday prayers in congregation. All activities that involve all school members such as students, teachers and employees. In learning the Qur'an there are activities tahsin tahfidz with the Tsaqifa method, learning through the Tsaqifa application, learning from nothing to something. Tsaqifa method is very suitable for students who have never studied the Qur'an or their reading is still stammering.

Relevant research is in accordance with the article "Implementation of students' religious character education through tahfidz Quran tahsin activities at Muhammadiyah vocational high school 3 Surakarta", including research conducted by:

Ahmad Fatah examined the success of Islamic education in the Qur'an tahfidz program. ${ }^{2}$ Evinna and Arnold examined the implementation of character education in schools through example and habituation. ${ }^{3}$ Tamrin examined the pattern of guidance of the Qur'anic tahsin among students. ${ }^{4}$ Saiful Habib

\footnotetext{
${ }^{2}$ Ahmad Fatah, “Dimensi Keberhasilan Pendidikan Islam Program Tahfidz Al-Qur'an”, Jurnal Penelitian Pendidikan Islam, Vol. 9, No. 2, (2014): 335-356.

${ }^{3}$ Evinna and Arnold, "Implementasi Pendidikan Karakter melalui Keteladanan dan Pembiasaan”, Jurnal Pendidikan Dasar Indonesia, Vol. 1, No. 2, (2016): 24-29.

${ }^{4}$ Tamrin, "Pola Pembinaan Tahsin Al-Quran di Kalangan Mahasiswa", Jurnal Rausyah Fikr, Vol. 12, No. 2, (2016): 315-350
} 
examined the development of Web-based tahfidz Qur'an recitation. ${ }^{5}$ Cucu Susianti examined the effectiveness of the Talaqqi method in improving the ability to memorize the Qur'an. ${ }^{6}$ Muhammad Sadli Mustafa examined the implementation of the method of learning tahsin and tahfidz of the Qur'an in Madrasah. ${ }^{7}$ Syarif, Rahendra, and Agus examined the implementation of at-tahsin in improving the ability to read the Qur'an at the Al-Qur'an Education Park. ${ }^{8}$ Ali Muhsin examined the effect of Al-Qur'an Education Park on improving the Quran's tahfidz program. ${ }^{9}$ Yuanita and Romadon examined character education through learning the Qur'an tahfidz. ${ }^{10}$ Umar examines the implementation of learning the Qur'an tahfidz. ${ }^{11}$

Bobi Erno Rusadi examined the implementation of tahfidz tahsin learning in Islamic boarding schools. ${ }^{12}$ Mohammad Iqbal Ansari examined the implementation of the 30-day tahfidz Qur'an quarantine..$^{13}$ Abdul Qawi examined the improvement in the learning of memorizing the Qur'an through the Talaqqi method. ${ }^{14}$ Eny and Febi examined the strengthening of religious-based character

${ }^{5}$ Saiful Habib, "Pengembangan Tahsin Tahfidz Al Quran Berbasis Web di SMA Ihsanul Fikri”, Jurnal Pendidikan, Vol. 20, No. 1, (2016): 1-7

${ }^{6}$ Cucu Susianti, "Efektifitas Metode Talaqqi dalam Meningkatkan Kemampuan Menghafal Al-Quran Anak Usia Dini.", Jurnal Tunas Siliwangi, Vol. 2, No. 1, (2016): 1-19

${ }^{7}$ Muhammad Sadli Mustafa, "Pelaksanaan Metode Pembelajaran Tahfidz Al-Quran di Madrasah Tahfidz Al-Quran Al-Imam “Ashim Tidung Mariolo, Makassar.”, Al-Qalam, Vol. 18, No. 2, (2012): 245-252

${ }^{8}$ Syarif, Rahendra and Agus, "Implementasi Metode Tahsin dalam Meningkatkan Kemampuan Membaca Al-Quran pada Taman Pendidikan Al-Quran (TPA) Hunafa Anak Shaleh dan Shalehah Kecamatan Jagarkarsa Kota Jakarta Selatan", Jurnal Prosa PAI, Vol. 1, No. 1, (2018): 75-87

${ }^{9}$ Ali Muhsin, "Pengaruh TPA Terhadap Peningkatan Program Tahfidz Quran di SMP Al Islam Mojokerto. Jurnal Kuttab, Vol. 1, No. 2, (2012): 216-224

${ }^{10}$ Yuanita and Romadon, "Pendidikan Karakter Melalui Pembelajaran Tahfidz Al Quran Siswa SDIT Al Bina Pangkalpinang.”, Jurnal JPSD, Vol. 5, No. 1, (2018): 1-6

${ }^{11}$ Umar, "Implementasi Pembelajaran Tahfidz Al-Quran di SMP Luqman Al-Hakim.”. Jurnal Tadarus, Vol. 6, No. 1, (2017): 1-21.

${ }^{12}$ Bobi Erno Rosadi, "Implementasi Pembelajaran Tahfidz Al-Quran Mahasantri Pondok Pesantren Nurul Quran Tangerang Selatan.”, Jurnal Agama dan Pendidikan Islam, Vol. 10, No. 2, (2018): 268-282

${ }^{13}$ Muhammad Iqbal Ansori, "Pelaksanaan Karantina Tahfidz Al-Quran 30 Hari untuk Siswa Sekolah Dasar di Banjarmasin.”, Jurnal Madrasah Ibtidaiyah, Vol. 2, No. 2, (2017): 1-18.

${ }^{14}$ Abdul Qawi, "Peningkatan Prestasi Belajar Hafalan Al-Quran Melalui Metode Talaqqi di MTSN Gampong Teungah Aceh Utara.”. Jurnal Islam Futura, Vol. 16, No. 2, (2017): 265-283. 
education. ${ }^{15}$ Zulfitria examined the role of learning the Qur'an tahfidz in character education. ${ }^{16}$ Rafi Andi Wibawa examined the education of tahsin tahfidz in BTQ learning. ${ }^{17}$ Wiwik Anggranti examined the application of learning to read the Qur'an. ${ }^{18}$ Aliwar examines the strengthening of the Tahfidz Tahsin learning model in learning to read and write the Qur'an. ${ }^{19}$ Srijatun examined the implementation of BTA learning with the Iqro method. ${ }^{20}$ Jamhuri (2016) examined the use of drill methods in improving students' reading ability in the Qur'an. ${ }^{21}$

Analysis of differences with the article Implementation of religious character education through tahsid tahfidz Qur'an with the Tsaqifa method in Muhammadiyah vocational high School 3 Surakarta. The difference is that if other researchers only analyze general or varied methods that can be used in tahfidz tahsin learning, but in this article there is specialization in using the way of teaching tahsidh tahsin by using the Tsaqifa method. Thus the learning method of the Qur'an, which is effective and pleasing to students can be known. The process of learning tahsin and tahfidz Al-Qur'an with Tsaqifa method is learning that has a way or method in learning and deepening the Qur'an. Reading the Qur'an is one of the religious character education programs in Muhammadiyah vocational high School 3 Surakarta. This article aims to describe 1) The application of religious character education through tahsin and tahfidz activities with Tsaqifa method in learning the Qur'an at Muhammadiyah

${ }^{15}$ Eny and Febi, "Penguatan Pendidikan Karakter Berbasis Religius.", Jurnal Ciastech, Vol. 2, No. 1, (2018): 1-9

${ }^{16}$ Zulfitrian, "Peranan Pembelajaran Tahfidz Al-Quran dalam Pendidikan Karakter di Sekolah Dasar.", Jurnal Penelitian Pendidikan dan Pembelajaran, Vol. 1, No. 2, (2017): 124-134.

${ }^{17}$ Rafi Andi Wibawa, "Pendidikan Baca Tulis Al-Quran di SMK Muhammadiyah 1 Taman Sidoarjo.", Jurnal Pendidikan Islam, Vol. 2, No. 2, (2018): 182-189

${ }^{18}$ Wiwik Anggranti, "Penerapan Metode Pembelajaran Baca Tulis Al-Quran di SMP Negeri 2 Tenggarong.", Jurnal Intelegensia, Vol. 1, No. 1, (2016): 106-119

${ }_{19}$ Aliwar, "Penguatan Tahsin Tahfidz dalam Pembelajaran Baca Tulis Al-Quran.". Jurnal AlTa'dib, Vol. 9, No. 1, (2016): 21-37.

${ }^{20}$ Srijatun, “Implementasi Pembelajaran Baca Tulis Al-Qur'an dengan Metode Iqro pada Anak Usia Dini di RA Perwanida Slawi Kabupaten Tegal.”, Jurnal Pendidikan Islam, Vol. 11, No. 1, (2017): 26-42.

${ }^{21}$ Jamhuri, "Penggunaan Metode Drill dalam Meningkatkan Kemampuan Membaca AlQuran Siswa di SMK Dewantoro Purwosari.", Jurnal El Murabbi, Vol. 1, No. 2, (2016): 201-216. 
vocational high School 3 Surakarta. 2) Supporting and inhibiting factors of the application of the Tsaqifa method, and 3) results in the activities of tahsin and tahfidz of the Qur'an using the Tsaqifa method.

\section{METHOD}

This research uses the type of field research methods using qualitative research types. Sources of data in this study were teachers, students, and the learning process of the Qur'an subjects at Muhammadiyah vocational high School 3 Surakarta.

The object of this study is the teaching method used by the teacher in learning to read and write the Qur'an. This research was conducted at Muhammadiyah vocational high School 3 Surakarta with class X TKJ, XI TKJ, X TITL, XI TITL, X TAV, XI TAV respondents. The time used to conduct research is semester 1 of the 2019/2020 school year.

A technique or ways that can be used by researchers to collect data. In order to obtain data, the researchers used data collection methods such as: Interviews, observations, and library documentation. Interview stage, interview is a way of collecting data that is used to obtain information directly from the source, conducted with subject teachers and students of class X and XI all skills programs. The observation phase, the method of observation is a way for technique to collect data by making direct observations of the activities being examined, carried out during the learning process of the Qur'an. The documentation / library stage, this technique is a way of collecting data through written data, mainly in the form of archives and including books on opinions, theories, propositions / laws, and others related to research problems.

\section{RESULTS AND DISCUSSION}

Application of Religious Character Education through Tahsin and Tahfidz Qur'an Activities using the Tsaqifa Method 
Based on research that has been done, data obtained include: 1) Observation Results; 2) Results of interviews with religious teachers; 3) Results of interviews with students; 4) Documentation during conducting research. The steps of learning tahsin and tahfidz with Tsaqifah method are carried out during the Qur'an subjects and during the first hour on all subjects of religious education. Like, worship, dates and Arabic language, just started at this new school year 2019/2020. The tahsin and tahfidz programs with the Tsaqifa method at Muhammadiyah vocational high School 3 Surakarta are one of the programs intended for students who cannot read the Qur'an until they become the students who can read the Qur'an as a peer tutor, helping other students understand. The application of Tsaqifa method in learning to read the Qur'an is carried out using techniques by listening one by one.

Muhammadiyah 3 Vocational School Surakarta is an Islamic-based Muhammadiyah school, which has accreditation A and has a mandatory superior learning program given to the Qur'an subjects namely tahsin and tahfidz. Where students are required to read and memorize the Qur'an every day, which is targeted after graduating from Vocational School can memorize a minimum of 30 juz or at least can read the Qur'an smoothly. The method used in learning tahsin and tahfidz Alquran with Tsaqifa method. The learning process of Tahsin and Tahfidz with Tsaqifa method is starting from students understanding from zero, reciting, to memorizing with what is exemplified by the teacher for each group of tahsin and tahfidz learning, then students are followed and then justified by the teacher, if there is a pronunciation error.

Based on the interview from the supervising teacher, the main purpose of the implementation of this program is to facilitate students in the school to learn the meaning of letters and tajwid correctly and to familiarize students to interact with the Koran. The purpose of the establishment of this program is that students at SMK Muhammadiyah 3 can read the Koran with mahraj and its correct tajwid rules, because the obligation to read the Koran with mahraj and the correct rules is not only intended for Islamic Religious Education teachers 
but for all Muslims. Thus the students at SMK Muhammadiyah 3 Surakarta are required to learn mahraj and the rules of recitation according to what the Prophet taught to become students who love the Koran, so they can practice the Koran in everyday life.

The implementation process uses the Tsaqifa method, namely the existence of a supervisory teacher by the Islamic Religious Education Teacher, the teacher provides an explanation of the rules that must be considered in the reading. And the tahfidz program for those who have met the criteria, while for students whose reading is still stuttering they must repeat the reading and continue to study until they can. The material is taken from the Tsaqifa book or the Tsaqifa application. Learning materials are arranged systematically, coherently, and continuously.

Tsaqifa method facilitates the learning process and teaches how to read the Qur'an quickly and easily understood, because of pictures and writing that are easy to understand, students can learn the Qur'an with fun, and lighten the teacher's limited burden in terms of teaching time.

Based on observations and interviews from the tutor, the reason for using the Tsaqifa method in learning the Qur'an at Muhammadiyah vocational high School 3 Surakarta, namely:

1) The learning patterns that are used in each discussion are fixed, sequential, and continuous patterns so that students can easily understand;

2) This method can be taught with private or classical systems and can be taught to all parents and children (10 years and above);

3) To be able to read the Qur'an requires a short time, the target is 1 year fluent reading, but usually less than one year they are able to read;

4) Each discussion or chapter has a different teaching so that it is interesting, not boring, and does not give burden;

5) Active students learning style, the teacher can just listen and justify the mistakes. 
The system used in the Tsaqifa method at Muhammadiyah vocational high School 3 Surakarta is a system of 5 meetings per chapter, if in 5 meetings students have mastered one meaningful chapter they move to the next chapter. And it is hoped that within one year students are able to read the Qur'an smoothly.

This Tsaqifa method provides a practical guide to the stages of continuous learning. The Tsaqifa Method divides the material into 9 chapters of the discussion phase.

Chapter 1: Introduction of 18 hijaiyah letters and their changes.

Chapter 2: Introduction of 10 hijaiyah letters and their changes

Chapter 3: Introduction of fathah, kasroh, and dhommah punctuation marks.

Chapter 4: Introduction of harwin / tanwin punctuation.

Chapter 5: Introduction to long reading (Mad).

Chapter 6: Introduction of dead reading

Chapter 7: Double letter recognition (tasydid).

Chapter 8: Reading Practice

Chapter9: Tajweed applied the Tsaqifa method.

In addition to the Tsaqifa method the teacher also conveys material using other methods, namely lecture. In more detailed steps in the application of learning the Qur'an with Tsaqifa method at Muhammadiyah vocational high School 3 Surakarta include preparation, implementation, and follow-up.

Preparation: Preparing the application for the Tsaqifa method, explaining the use of the Tsaqifa application, preparing a peer mentor who can read the Qur'an by holding a test first, which meets the criteria for a mentor.

Implementation: Students who are selected to be mentors must teach students who cannot read the Qur'an, each student mentor teaches one student 
who cannot read the Qur'an (per individual), in the Tsaqifa method there are chapter divisions, mentors teach each tsaqifa participant per chapter until they can, if a Tsaqifa participant is declared to be by a peer mentor, then a Tsaqifa participant deposits it to the supervisor, and is declared to pass if the reading of the chapters is read smoothly.

Follow-up: 1) For students who have not read correctly per chapter then they must repeat again until they can; 2) For students who have read it correctly per chapter, go to the next chapter, etc ; 3) In Tsaqifa there are 9 chapters, if declared to pass / finish by the supervising teacher then students are declared to pass the Qur'an subjects.

By carrying out the activities of tahsid tahfidz of the Qur'an with this Tsaqifa method students will know the Qur'an, recite the Qur'an smoothly, and can learn the contents in it. By always learning the Qur'an and understanding the Qur'an then the character of students will be more guided because they have instructions for life, in doing things they will also know whether the action taken is true or false. Internalization of religious values to students is necessary to optimize education, such as the formation of religious character through tahsin and tahfidz Qur'an with the Tsaqifa method conducted at Muhammadiyah vocational high School Surakarta

The activities of tahsin and tahfidz Qur'an can form a good personality. People who perform tahfidzul Qur'an are related to good character because it becomes a measure in personality, especially in character formation, so that habituation through reading and memorizing the Qur'an will form a religious character that will be inherent in the child's personality. 
Supporting and Inhibiting Factors of Tahsid Tahfidz Quran activities using the Tsaqifa Method

The supporting factors for the success of the Tahsin Tahfidz Quran activities with the Tsaqifa method in Muhammadiyah vocational high School 3 Surakarta are:

1) The existence of adequate place is one of the supporting factors so that the activities run well so that the participants feel comfortable when studying in the room.

2) Students who are eager to learn the Tsaqifa method, a very important initial capital one of which is to have a high enthusiasm for learning so that students are more active in learning to use this method.

3) Students have the intention to learn the Qur'an, this is one of the important factors because if it is based on a strong curiosity it will facilitate learning and accelerate the learning process of students.

4) Students who are istiqomah in learning that shows the discipline of learning the Qur'an. One of the keys for us to quickly understand is that we are always diligent in learning every day, continuously and repeatedly which makes us fast.

5) Students are very patient in learning, always willing to ask questions or repeat readings until they are able to read. Students who actively ask questions if they don't know the reading or the punctuation marks have reciprocal relationships wiht the teacher which makes learning activities active and efficient. It is true that if you don't know, ask, do not be quiet. By asking, the teacher will know which students are still in need of help.

6) Peer tutors who also play an active role in teaching students of Tsaqifa participants, do not have to be teachers who teach but peers if they are able to help teach their peers who cannot. Because friends with friends will usually be more comfortable or can be closer so if you want to ask questions don't be shy. And the tutor at least knows more about the friends being taught so that the delivery of material can be adjusted according to the 
conditions of the theme so that the material is appropriate and can be well received by students.

7) The teacher gives a clear explanation in directing the practice of the Tsaqifa method, so students understand how to practice using this method the teacher must really teach the steps that students must take in learning to use this method.

8) Leaders who fully support the implementation of the tahsin and tahfidz programs using the Tsaqifa method, is one of the important driving factors. Leaders must also provide motivation to students to be more motivated in learning and the leader should provide support so that the activity runs smoothly.

9) Teachers and employees who are very supportive of the Tsaqifa method in Qur'an learning that was coined by the supervising teacher.

10) The equipment that supports the activities of the Qur'an tahfidz with Tsaqifa method is also very adequate. Good facilities are one of the important factors in supporting the activities of the Qur'an tahfidz.

With the supporting factors of this activity, it greatly supports the success of the Tahfidz Tahsin activities with the Tsaqifa method, with the supporting factors the purpose of this activity, so that students who initially cannot read the Qur'an can be able to set a predetermined time target. The supporting factors of the activities of the tahfidz Qur'an with Tsaqifa method are very helpful to the supervising teacher to achieve the objectives of this activity. If the activity which just started in the 2019/2020 school year is successful and effective for students in learning the Qur'an, surely this activity will be more noticed and developed again from school. There needs to be a review to support the activities of the tahfidz tahsin Qur'an by using the Tsaqifa method to run well and to experience a very significant increase in results for students.

The inhibiting factors of tahfidz tahsin Quran activities with Tsaqifa method in Muhammadiyah vocational high School 3 Surakarta are: 
1) One of the factors causing the obstruction of tahfidz tahsin activities is that students who do not understand the material per chapter become afraid to deposit to the supervisor.

2) Less conducive to class, when students deposit material per chapter that has been mastered, students are not focused because they are disturbed by the classroom atmosphere.

3) There are misunderstandings with peer tutors, sometimes students do not want to follow their peer tutors.

4) The ability of each students are different, sometimes with a target of 5 meetings per chapter, but students are not entirely the same in mastering the discussion chapter.

The factors that cause students difficulties in learning the Tsaqifa method are internal factors, the low intelligence capacity of students to understand, the instability of emotions and attitudes make students complain because they are impatient and quickly feel bored in applying this tsaqifa method. Because who guides them are their peers which makes them play a lot. Causes of external factors include family environment, community environment, and others.

To overcome each problem or inhibiting factors are still being studied to find the right solution. The process of learning tahsin and tahfidz Qur'an with Tsaqifa method is a type of learning that has a way in deepening the ability to read the Qur'an. Reading the Qur'an by looking at the mushaf has actually begun the process of memorization. With us reading the Qur'an verses repeatedly, it is the initial technique for the process of memorizing the Qur'an.

The learning process certainly requires careful and systematic planning and preparation so that the learning process can be effective. Tsaqifa method not only serves to attract learning interest and reduce student boredom, but also to improve learning effectiveness. The new Tsaqifa method is applied in the $2019 / 2020$ school year so there are still obstacles in realizing it, it is necessary to study what solutions are appropriate to use. 
The assessment is done through monitoring and evaluation carried out by the Principal. It has relatively fast time to understand the material, within 5 meetings students should to be able to read the Qur'an well and does not require a lot of time.

Results of Tahfidz Tahsin Activity Using the Tsaqifa Method

Based on interviews from mentors of tahsin and tahfidz supervisors at Muhammadiyah vocational high School 3 Surakarta that during the first semester there was an improvement in the quality of reading the Qur'an from students who had entered school early and could not read the Qur'an well even they had not memorized or knew hijaiyah letters and now began to see its development.

This Tsaqifa method is very effectively applied in Muhammadiyah vocational high School 3 Surakarta. This can be seen from the results of learning where most students can quickly read the Qur'an independently although only limited reading. Besides that, according to students, the method used is in accordance with what they need, which is to be able to read the Qur'an in accordance with the makhorijul letters and recitation in a relatively short time in the midst of the density of other school activities.

Reading (tahsin) and Memorization (tahfidz) of the Qur'an is a process of memorizing memorized material that must be perfect, because the knowledge is learned to be memorized to be understood, but after perfectly memorizing the Qur'an, then the next is required to know the contents contained therein. Someone who intends to memorize the Qur'an is advised to know the material related to memorization. The process of learning tahsin and tahfidz Qur'an with Tsaqifa method is learning that has a way or method in learning and deepening the Qur'an. Reading the Qur'an by looking at the mushaf has actually begun the process of memorization. With us reading the verses of the Qur'an repeatedly is the initial technique in the process of memorizing the Qur'an. 
Tsaqifa learning methods are important in supporting the success of learning. In shaping the religious character of students at Muhammadiyah vocational high School 3 Surakarta through tahsin and tahfidz Qur'an activities using the Tsaqifa method. Tsaqifa method, a method of learning to read and write the Qur'an as an alternative to overcome illiteracy of the Qur'an among Muslims. This method is specifically designed for adults who have not been able to read the Qur'an or for those who have learned but still stammer to read it. In this Tsaqifa method, systematic in learning, the discussion is varied and practical, so it will be easier for students to understand.

Based on student observations and interviews, students who initially never read the Qur'an, are lazy to learn the Qur'an, viewed from observations within one month in class X and XI all skills competency programs, student enthusiasm in learning the Qur'an is high because of the Tsaqifa method in learning the Qur'an is an effective method, varied discussion, systematic, and more easily understood by students.

Other learning outcomes that can be seen are the activeness of the students, interaction with peer tutors, interaction with the accompanying teacher by giving a reading deposit, or repeating the reading if it is not yet smooth. Tahsin and tahfidz students are in accordance with the correct rules in learning the Qur'an, both in terms of recitation and their fluency in reading. The relationship between students and friends is closer, the relationship between teacher and students is also closer, without reducing the boundary between teacher and student. The teacher can recognize the cognitive and personal abilities of students one by one, and students also get to know their teacher more so that students value and respect the knowledge and abilities possessed by the teacher.

The results of the Tsaqifa method, that Tsaqifa is a direct, effective, and intensive method of teaching the Qur'an individually. This method is a very modern method, the teacher learns to master the material that needs to be taught, so do students also learn to make preparations before depositing the 
reading. So as to produce good performance, which is able to place their respective positions both teachers and students.

From the results of observations for 1.5 months with respondent students X TKJA, X TKJB, XI TKJ, X TITL, XI TITL, X TAV, XI TAV, who initially are students that have no fluency in reading the Qur'an, have not memorized hijaiyah letters and have never even learned the Qur'an at all, learn from zero, with this Tsaqifa method even though it only began in the 2019/2020 school year many developments were achieved:

1) Students can express the sound of hijaiyah letters properly and correctly in accordance with the makhrojiul hurf.

2) Students are able to read the Quran's lafadz starting from word to word then continuing from verse to verse correctly.

3) Students are accustomed to reading Arabic texts from right to left.

4) Students who initially could not and did not recognize Arabic texts, could read Arabic texts correctly and smoothly.

The success achieved in the learning process is not spared the hard work of an educator, namely the process of teaching and learning activities ranging from growing, fostering, shaping and empowering all potentials possessed by students, or the extent to which educators provide significant changes in cognitive abilities, affective, and psychomotor in students.

In the Tsaqifa method there are keys to success that need to be considered:

1) Exercise regularly, activate the tongue with a lot of reading Tsaqifa per chapter or discussion both in class and when at home.

2) Train the tongue in accordance with makhorijul letters, if you do not know the correct makhorijul hurf, then ask the peers who become the tutor.

3) The ability to read is determined flying hours reading by repeating per chapter or discussion. If it is smooth, then continue on the next page and 
the next chapter. And will not continue to the next page if you have not mastered and read fluently.

4) Active, because a passive attitude will slow the process of success in this Tsaqifa method. With students always wanting to learn the Qur'an, practice it often, ask the one who understands better, the desire to immediately be able to read the Qur'an is high.

5) Often in listening to the recitations of others, in person or through mobile phones, CDs, view videos about reading the Qur'an etc. can support the success of the Tsaqifa method. Because by frequently listening to the reading of the Qur'an will greatly help the memory of the sound pronunciation of the letters of the Qur'an.

Character education must be integrated in religious education. The role of religion can meet human needs in terms of the director, guide, and balancing character of students. People who do tahfidzul Qur'an relate to good morals because morals will be a good measure in personality, especially in the formation of character. Through the activities of tahsidh tahsidz the Qur'an with Tsaqifa method shows an increase in reading the Qur'an on students at Muhammadiyah vocational high School 3 Surakarta. This greatly affects the level of religious character of students who initially could not read the Qur'an then showed significant developments by being able to read even though they were stuttering, could only read without the rules of recitation, and would proceed to read according to recitation, to memorizing the Qur'an. Students show their passion in reading the Qur'an during the learning process and during breaks.

\section{CONCLUSIONS}

Based on the results of research and discussion, the following conclusions can be drawn: 
1) Implementation of the activities of tahsin and tahfidz with the Tsaqifah method are carried out during the Qur'an subjects and during the first hour on all subjects of religious education. Like worship, tarikh and Arabic, it just started running at this new school year 2019/2020. The tahsin and tahfidz programs with the Tsaqifah method at Muhammadiyah vocational high School 3 Surakarta are one of the programs intended for students who cannot read, start learning from zero until they can, and who can already be peer tutors, helping other students to understand. The system used in the Tsaqifa method at Muhammadiyah vocational high School 3 Surakarta is a system of 5 meetings per chapter, if in 5 meetings students have mastered one meaningful chapter, they can move to the next chapter. This Tsaqifa method provides a practical guide to the stages of continuous learning. And it is hoped that within one year they will be able to read the Qur'an smoothly. In more detailed steps in the application of learning the Qur'an with Tsaqifah method at Muhammadiyah vocational high School 3 Surakarta include preparation, implementation, follow-up.

2) Supporting factors are adequate place, teacher participation, and students who are eager to learn the Qur'an using the Tsaqifa method, as well as full support from leaders and employees for the implementation of the tahsin and tahfidz programs with the Tsaqifa method. The factors that cause students difficulties in learning the Qur'an using the Tsaqifa method are internal factors, the low intelligence capacity of students to understand, the instability of emotions and attitudes make students complain because they are impatient in applying this tsaqifa method. External factors, family environment, community environment, and others.

3) Based on interviews from mentors of tahsin and tahfidz supervisors at Muhammadiyah vocational high School 3 Surakarta that during one semester there was an improvement in the quality of reading the Qur'an from students who initially entered school could not read the Qur'an 
well. In addition, according to students, the method used is in accordance with what they need, which is to be able to read the Qur'an in a relatively short time in the midst of the density of other school activities. Tahsidz tahsin activities with Tsaqifa method greatly affect the level of religious character of students who initially could not read the Qur'an then showed significant development.

\section{REFERENCES}

Qawi, Abdul, "Peningkatan Prestasi Belajar Hafalan Al-Quran Melalui Metode Talaqqi di MTSN Gampong Teungah Aceh Utara." Jurnal Islam Futura, Vol. 16, No. 2, 2017, pp. 265-283. http://jurnal.arraniry.ac.id/index.php/islamfutura/article/download/1327/1150

Fatah, Ahmad, "Dimensi Keberhasilan Pendidikan Islam Program Tahfidz AlQur'an.”, Jurnal Penelitian Pendidikan Islam, Vol. 9, No. 2, 2014, pp. 335-356. http://journal.stainkudus.ac.id/index.php/Edukasia/article/view/779

Muhsin, Ali, (2017). "Pengaruh TPA Terhadap Peningkatan Program Tahfidz Quran di SMP Al Islam Mojokerto.", Jurnal Kuttab, Vol. 1, No. 2, 2017, pp. 216-224.

http://journalfai.unisla.ac.id/index.php/KUTTAB/article/view/114

Aliwar, "Penguatan Tahsin Tahfidz dalam Pembelajaran Baca Tulis Al-Quran.”. Jurnal Al-Ta'dib, Vol. 9, No. 1, 2016, pp. 21-37, http://ejornal.iainkendari.ac.id/al-tadib/article/download/500/486

Asmani, Buku Panduan Internalisasi Pendidikan Karakter di Sekolah. Yogyakarta: Diva Press, 2011.

Rosadi, Bobi Erno, "Implementasi Pembelajaran Tahfidz Al-Quran Mahasantri Pondok Pesantren Nurul Quran Tangerang Selatan.", Jurnal Agama dan Pendidikan Islam, Vol. 10, No. 2, 2018, pp. 268-282. http://jurnal.umsu.ac.id/index.php/intiqad

Susanti, Cucu, (2016). "Efektifitas Metode Talaqqi dalam Meningkatkan Kemampuan Menghafal Al-Quran Anak Usia Dini.". Jurnal Tunas Siliwangi, Vol. 2, No. 1,2016, pp. 1-19. http://ejournal.stkipsiliwangi.ac.id/index.php/tunassiliwangi/article/download/305/226

Evinna and Arnold, "Implementasi Pendidikan Karakter melalui Keteladanan dan Pembiasaan.", Jurnal Pendidikan Dasar Indonesia, Vol. 1, No. 2, 2016, pp. 
25-29.

http://journal.stikipsingkawang.ac.id/index.php/JPDI/article/view/262

Eny and Febi, "Penguatan Pendidikan Karakter Berbasis Religius.", Jurnal Ciastech, Vol. 2, No. 1, 2018, pp. 1-9. http://publishing-widyagama.ac.id/ejournalv2/index.php/ciastech/article.viewFile/630/582

Nashir, Haedar, Pendidikan Karakter Berbasis Agama dan Budaya. Yogyakarta: MultiPressindo, 2013.

Jamhuri, "Penggunaan Metode Drill dalam Meningkatkan Kemampuan Membaca Al-Quran Siswa di SMK Dewantoro Purwosari.". Jurnal El Murabbi, Vol. 1, No. 2, 2016, Pp. 201-216. http://jurnal.yudharta.ac.id/v2/index.php/pai/article/download/395/300

Ansari, Muhammad Iqbal, "Pelaksanaan Karantina Tahfidz Al-Quran 30 Hari untuk Siswa Sekolah Dasar di Banjarmasin.”, Jurnal Madrasah Ibtidaiyah, Vol. 2, No. 2, 2017, pp. 1-18. http://ojs.uniskabjm.ac.id/index.php/muallimun

Mustafa, Muhammad Sadli, "Pelaksanaan Metode Pembelajaran Tahfidz Al-Quran di Madrasah Tahfidz Al-Quran Al-Imam 'Ashim Tidung Mariolo, Makassar.", Jurnal Al Qalam, Vol. 18, No. 2, 2012, pp. 245-252. http://www.jurnalalqalam.or.id/index.php/Alqalam/article/view/73/66

Mulyasa, Manajemen Pendidikan Karakter, Jakarta: Bumi Aksara, 2012

Wibawa, Rafi Andi, "Pendidikan Baca Tulis Al-Quran di SMK Muhammadiyah 1 Taman Sidoarjo.". Jurnal Pendidikan Islam, Vol. 2, No. 2, 2018, pp. 182-189. http://ojs.umsida.ac.id/index.php/halaqa

Habib, Saiful, "Pengembangan Tahsin Tahfidz Al Quran Berbasis Web di SMA Ihsanul Fikri.", Jurnal Pendidikan, Vol. 20, No. 1, 2016, pp. 1-7. http://journal.student.uny.ac.id/ojs/index.php/pai/article/viewFile/4725 $/ p d f$

Srijatun, “Implementasi Pembelajaran Baca Tulis Al-Qur'an dengan Metode Iqro pada Anak Usia Dini di RA Perwanida Slawi Kabupaten Tegal.", Jurnal Pendidikan Islam, Vol. 11, No. 1, 2017, pp. 26-42. http://journal.walisongo.ac.id/index.php/Nadwa/article/download/Pemb elajaran\%20BTA/pdf

Syarif, Rahendra and Agus. "Implementasi Metode Tahsin dalam Meningkatkan Kemampuan Membaca Al-Quran pada Taman Pendidikan Al-Quran (TPA) Hunafa Anak Shaleh dan Shalehah Kecamatan Jagarkarsa Kota Jakarta Selatan.", Jurnal Prosa PAI, Vol. 1, No. 1, pp. 75-87. http://jurnal.staialhidayahbogor.aci.id/index.php/ppai/article/download $/ 298 / 262$ 
Tamrin, "Pola Pembinaan Tahsin Al-Quran di Kalangan Mahasiswa." Jurnal Rausyah Fikr, Vol. 12, No. 2, 2016, pp. 316-350. . http://jurnal.iainpalu.ac.id/index.php/rsy/article/download/87

Umar, "Implementasi Pembelajaran Tahfidz Al-Quran di SMP Luqman Al-Hakim." Jurnal Tadarus, Vol. 6, No. 1, 2017, pp. 1-21. http://journal.umsurabaya.ac.id/indez.php/Tadarus/article/download/934/pdf

Anggranti, Wiwik, "Penerapan Metode Pembelajaran Baca Tulis Al-Quran di SMP Negeri 2 Tenggarong.”, Jurnal Intelegensia, Vo. 1, No. 1, 2016, pp. 106-119. http://ejurnal.unikarta.ac.id/index.php/intelegensia/article/download/2 $36 / 198$

Yuanita and Romadon, "Pendidikan Karakter Melalui Pembelajaran Tahfidz Al Quran Siswa SDIT Al Bina Pangkalpinang." Jurnal JPSD, Vol. 5, No. 1, 2018, pp. 1-6.

http://journal.uad.ac.id/index.php/JPSD/article/download/12577/6235

Zulfitria. "Peranan Pembelajaran Tahfidz Al-Quran dalam Pendidikan Karakter di Sekolah Dasar.", Jurnal Penelitian Pendidikan dan Pembelajaran, Vol. 1, No. 2, 2017, pp. 124-134.

http://journal.umtas.ac.id/index.php/naturalistic/article/download/9/15 